\title{
Analisis Kompetensi Mahasiswa Calon Guru Fisika Pada Peer Teaching Berdasarkan Kurikulum 2013 Pada Perkuliahan PPL
}

\author{
Nurasyah Dewi Napitupulu \\ email: nurdewi661@yahoo.com \\ Program Studi Pendidikan Fisika, Jurusan Pendidikan MIPA, Universitas Tadulako \\ Jl. Soekarno Hatta, KM.9, Kampus Bumi Tadulako Tondo Palu - Sulawesi Tengah
}

\begin{abstract}
ABSTRAK - Penelitian Ini bertujuan untuk menganalisis kompetensi mahasiswa calon guru fisika di Prodi pendidikan Fisika Universitas Tadulako pada semester genap tahun 2014. Kompetensi didasarkan atas Kurikulum 2013, menyangkut keterampilan menyusun Perencanaan Program Pembelajaran (PPP) dan keterampilan mengajar dengan menerapkan pendekatan Scientific secara benar. Sampel penelitian berjumlah 26 orang mahasiswa Prodi Fisika Angkatan 2012 kelas C yang mengambil perkuliahan PPL 1. Data dikumpulkan dengan menggunakan Instrumen Penilaian Perencanaan Pembelajaran (IPPP) dan Instrumen Lembar Kerja Analisis Pembelajaran berdasarkan kurikulum 2013. Data penelitian dianalisis dengan pendekatan kualitatifdeskriptif. Hasil penelitian menunjukkan bahwa kompetensi mahasiswa calon guru fisika merupakan Kompetensi Keterampilan Mengajar berada pada kategori kurang baik, dengan rata-rata skor 3,14. Sementara, Skor Penilaian Perencanaan Program Pembelajaran berada pada kategori baik, dengan rata-rata skor 3,72. Rendahnya kompetensi keterampilan mengajar mahasiswa calon guru fisika ini disebabkan aspek penguasaan materi yang berada pada kategori tidak baik, dengan rata-rata skor 2,27, dan aspek PPP tentang kejelasan skenario pembelajaran berada pada kategori kurangb baik, dengan rata-rata skor 3,27. Untuk meningkatkan kompetensi mahasiswa calon guru fisika diperlukan peer teaching yang lebih intensif, peningkatan penguasaan materi fisika melalui pembelajaran setiap mata kuliah, dan Dosen dalam pembelajaran di kelas harus menjadi model bagi mahasiswa calon guru, baik dari kompetensi kognitifnya maupun dalam kompetensi keterampilan mengajarnya.
\end{abstract}

Kata Kunci: kompetensi, Peer Teaching

\section{PENDAHULUAN}

Implementasi kurikulum 2013 telah dilaksanakan secara bertahap mulai tahun 2013, dimulai dari kelas 1 dan kelas 4 di sekolah dasar, kelas 7 di SMP dan kelas 10 di SMA. Pelaksanaannya dilakukan bagi sekolahsekolah sasaran mulai dari SD, SMP, SMA, dan SMK. Pelatihan kurikulum 2013 yang dirancang dan telah dan sedang dilaksanakan bertujuan agar guru mampu melaksanakan tugas sesuai dengan tuntutan kompetensi lulusan, isi, proses pembelajaran, dan penilaian Kurikulum 2013 itu sendiri [3].

Perubahan Kurikulum menjadi kurikulum 2013 berbasis kompetensi dan bertujuan untuk mempersiapkan manusia Indonesia agar memiliki kemampuan hidup sebagai pribadi dan warga negara yang beriman, produktif, kreatif, inovatif, dan afektif serta mampu berkontribusi pada kehidupan bermasyarakat, berbangsa, bernegara, dan peradaban dunia. Perubahan tersebut diperlukan mengingat kebutuhan pembangunan Indonesia dan tantangan gobal [4]. Salah satu tantangan internal yang dihadapi Indonesia adalah keikutsertaan Indonesia di dalam studi International Trends International Mathematics and Science Study (TIMSS) dan Program for International Student Assessment (PISA) sejak tahun 1999. Capaian anak-anak Indonesia tidak menggembirakan dalam beberapa kali laporan yang dikeluarkan TIMSS dan PISA. Hal ini disebabkan antara lain banyaknya materi uji yang ditanyakan di TIMSS dan PISA tidak terdapat dalam kurikulum Indonesia $[7,11]$.

Dinamisasi dunia pendidikan yang bertujuan meningkatkan kualitas pembelajaran senantiasa dilakukan untuk mengantisipasi perubahan yang senantiasa terjadi. Perubahan ini dimaksudkan untuk menciptakan kehidupan yang cerdas, damai, terbuka dan demokratis [10]. Terkait dengan hal itu, dalam pendidikan tinggi program pembelajaran diarahkan agar dapat memberikan motivasi dan inovasi pada mahasiswa dalam pembelajaran dan menelaah bidang ilmu yang dikaji.

Guru sebagai pelaksana pendidikan nasional merupakan faktor kunci, walaupun faktor lainnya tidak dapat diabaikan peranannya. Namun, guru yang berkualitas akan menghasilkan proses pembelajaran yang maksimal [1]. Jadi, proses pembelajaran yang maksimal didukung oleh guru yang mempunyai kompetensi tinggi. Guru merupakan ujung tombak dan pelaksana terdepan pendidikan 
dan pengembang kurikulum di sekolah. Berdasarkan hasil uji kompetensi guru diperoleh bahwa hanya $85 \%$ guru-guru di kota Palu yang lulus [9]. Sementara itu, hasil penelitian terhadap guru-guru IPA-Fisika SMP di kota Palu menunjukkan dimensi kompetensi guru yang terendah adalah kompetensi ketrampilan proses belajar mengajar [2]. Hasil ini menunjukkan bahwa kompetensi guru di kota Palu masih harus mendapat perhatian.

Perencanaan pembelajaran memegang peranan penting dalam meningkatkan kualitas pembelajaran. Tahap pertama dalam pembelajaran menurut standar proses adalah perencanaan pembelajaran yang diwujudkan dengan kegiatan penyusunan rencana pelaksanaan pembelajaran (RPP). Pada hakekatnya, Rencana pelaksanaan pembelajaran adalah rencana pembelajaran yang dikembangkan secara rinci dari suatu materi pokok atau tema tertentu yang mengacu pada silabus. RPP mencakup: (1) data sekolah, matapelajaran, dan kelas/semester; (2) materi pokok; (3) alokasi waktu; (4) tujuan pembelajaran, KD dan indikator pencapaian kompetensi; (5) materi pembelajaran; metode pembelajaran; (6) media, alat dan sumber belajar; (6) langkahlangkah kegiatan pembelajaran; dan (7) penilaian [8].

Sesuai dengan tujuan Kurikulum 2013 untuk menghasilkan peserta didik sebagai manusia yang mandiri dan tak berhenti belajar, proses pembelajaran dalam RPP dirancang dengan berpusat pada peserta didik untuk mengembangkan motivasi, minat, rasa ingin tahu, kreativitas, inisiatif, inspirasi, kemandirian, semangat belajar, keterampilan belajar dan kebiasaan belajar [5]. RPP disusun dengan memperhatikan keterkaitan dan keterpaduan antara KI dan KD, materi pembelajaran, kegiatan pembelajaran, penilaian, dan sumber belajar dalam satu keutuhan pengalaman belajar. Ini dilakukan dengan mengakomodasikan pembelajaran tematik, keterpaduan lintas matapelajaran untuk sikap dan keterampilan, dan keragaman budaya [8].

FKIP sebagai bagian dari dunia perguruan tinggi yang menyiapkan calon-calon guru berkualitas dan mempunyai kualitas kompetensi yang tinggi. Dengan perkuliahan yang dirancang sedemikian rupa mengikuti berbagai perubahan dan perkembangan berbagai model dan pendekatan pembelajaran, mahasiswa calon guru dipersiapkan sebagai calon guru yang tangguh. Salah satu perkuliahan yang bertujuan untuk melatih dan memperlengkapi mahasiswa calon guru menjadi guru yang kompeten dalam bidangnya adalah perkuliahan PPL (Program Praktek Lapangan). Pada Prodi Pendidikan Fisika Untad, perkuliahan PPL bertujuan untuk melatih kemampuan siswa dalam mengajar, sebelum mahasiswa praktek langsung di sekolah. Untuk itu mahasiswa dilatih dalam peer teaching berdasarkan Perencanaan Pembelajaran yang telah dipersiapkan sesuai dengan kurikulum 2013. Diharapkan kemampuan lulusan FKIP memenuhi standar kompetensi lulusan yang dapat mewujudkan tujuan pendidikan nasional. Standar Kompetensi Lulusan dimaksud merupakan kriteria mengenai kualifikasi kemampuan lulusan yang mencakup sikap, pengetahuan, dan keterampilan sebagaimana tertuang dalam kurikulum 2013 [3].

\section{II.METODOLOGI PENELITIAN}

Penelitian ini merupakan penelitian deskriptif yang menggunakan pendekatan kualitatif. Penelitian dilaksanakan di Program studi Pendidikan Fisika Jurusan PMIPA FKIP Universitas Tadulako Palu. Waktu penelitian pada semester genap Pebruari 2014 sampai Mei 2008. Subjek penelitian adalah mahasiswa Program Studi Pendidikan Fisika FKIP Untad Palu yang mengikuti perkuliahan PPL 1 . Objek penelitian ini adalah kompetensi keterampilan mengajar berdasarkan kurikulum 2013 pada peer teaching.

Data yang dikumpulkan dalam penelitian ini meliputi keseluruhan kegiatan peer teaching sebanyak tiga kali peer teaching yang diambil melalui observasi dengan Instrumen Penilaian Perencanaan pembelajaran (IPPP) dan Lembar Kerja Analisis Kompetensi Pembelajaran. Skor penilaian dengan rentang 1 - 4 dimana $1=$ sangat tidak baik, 2 = tidak baik, 3 = kurang baik, 4 = baik, 5 = sangat baik. Data meliputi: data skor kompetensi mahasiswa pada peer teaching dan skor IPPP.

Teknik analisis data dilakukan dalam tiga komponen berurutan: reduksi data, penyajian data, dan penarikan kesimpulan. Penarikan kesimpulan merupakan upaya pencarian makna data, mencatat keteraturan, dan penggolongan data. Data yang terkumpul disajikan secara sistematis dan diberi makna.

\section{III.HASIL DAN PEMBAHASAN}

Ada 15 aspek yang dinilai dalam Perencanaan Program Pembelajaran (PPP) dengan mengacu pada Kurikulum 2013. Hasil 
yang diperoleh terlihat pada tabel 1 di bawah ini.

Tabel 1. Skor Penilaian Perencanaan Program Pembelajaran

\begin{tabular}{|c|c|c|c|}
\hline No. & Aspek yang Dinilai & $\begin{array}{l}\text { Skor } \\
\text { (rata- } \\
\text { rata) }\end{array}$ & Kriteria \\
\hline 1 & $\begin{array}{lr}\text { Kesesuaian } & \text { pemilihan } \\
\text { kompetensi } & \text { dasar } \\
\text { dengan topik } & \\
\end{array}$ & 3,79 & baik \\
\hline 2 & $\begin{array}{lc}\text { Kesesuaian } & \text { perumusan } \\
\text { indikator } & \text { pencapaian } \\
\text { kompetensi } & \text { dengan } \\
\text { kompetensi dasar }\end{array}$ & 3,27 & $\begin{array}{l}\text { Kurang } \\
\text { baik }\end{array}$ \\
\hline 3 & $\begin{array}{l}\text { Kesesuaian perumusan } \\
\text { tujuan pembelajaran } \\
\text { dengan indikator } \\
\text { pencapaian kompetensi }\end{array}$ & 3,26 & $\begin{array}{l}\text { Kurang } \\
\text { baik }\end{array}$ \\
\hline 4 & $\begin{array}{ll}\text { Kejelasan } & \text { materi } \\
\text { pembelajaran } & \end{array}$ & 3,79 & baik \\
\hline 5 & $\begin{array}{l}\text { Kesesuaian materi } \\
\text { pembelajaran dengan } \\
\text { kompetensi dasar }\end{array}$ & 3,79 & baik \\
\hline 6 & $\begin{array}{l}\text { Kesesuaian metode } \\
\text { dengan tujuan, materi, } \\
\text { dan karakteristik } \\
\text { peserta didik }\end{array}$ & 3,26 & $\begin{array}{l}\text { Kurang } \\
\text { baik }\end{array}$ \\
\hline 7 & $\begin{array}{l}\text { Kejelasan skenario } \\
\text { pembelajaran (langkah- } \\
\text { langkah kegiatan } \\
\text { pembelajaran : } \\
\text { pendahuluan, inti, dan } \\
\text { penutup) }\end{array}$ & 3,27 & $\begin{array}{l}\text { Kurang } \\
\text { baik }\end{array}$ \\
\hline 8 & $\begin{array}{l}\text { Kerincian dan kejelasan } \\
\text { skenario pembelajaran } \\
\text { pada tahap kegiatan } \\
\text { eksplorasi }\end{array}$ & 3,79 & baik \\
\hline 9 & $\begin{array}{l}\text { Kerincian dan kejelasan } \\
\text { skenario pembelajaran } \\
\text { pada tahap kegiatan } \\
\text { elaborasi }\end{array}$ & 3,88 & baik \\
\hline 10 & $\begin{array}{l}\text { Kerincian dan kejelasan } \\
\text { skenario pembelajaran } \\
\text { pada tahap kegiatan } \\
\text { konfirmasi }\end{array}$ & 3,94 & baik \\
\hline 11 & $\begin{array}{l}\text { Ketepatan kegiatan } \\
\text { penutup dalam } \\
\text { pembelajaran }\end{array}$ & 4,18 & baik \\
\hline 12 & $\begin{array}{l}\text { Penilaian mencakup } \\
\text { aspek sikap, } \\
\text { pengetahuan, dan } \\
\text { keterampilan (holistik) }\end{array}$ & 4,19 & baik \\
\hline 13 & $\begin{array}{l}\text { Kesesuaian teknik } \\
\text { penilaian dengan } \\
\text { kompetensi yang akan } \\
\text { dicapai }\end{array}$ & 4,08 & baik \\
\hline
\end{tabular}

\begin{tabular}{|l|l|l|l|}
\hline 14 & $\begin{array}{l}\text { Kelengkapan perangkat } \\
\text { penilaian (soal, kunci, } \\
\text { rubrik penilaian) }\end{array}$ & 3,79 & baik \\
\hline 15 & $\begin{array}{l}\text { Keterpaduan dan } \\
\text { kesinkronan antar } \\
\text { komponen dalam RPP }\end{array}$ & 3,63 & baik \\
\hline \multicolumn{2}{|c|}{ Rata-rata } & $\mathbf{3 , 7 2}$ & baik \\
\hline $\begin{array}{l}1 \\
\text { kurang baik, 4 = baik, 5 = sangat baik. } \\
\text { Penetapan kriteria dengan pembulatan. }\end{array}$
\end{tabular}

Dari tabel 1 di atas terlihat bahwa dalam penulisan RPP mahasiswa masih kurang baik dalam 4 aspek penilaian. Keempat aspek tersebut adalah Kesesuaian perumusan indikator pencapaian kompetensi dengan kompetensi dasar; Kesesuaian perumusan tujuan pembelajaran dengan indikator pencapaian kompetensi; Kesesuaian metode dengan tujuan, materi, dan karakteristik peserta didik; Kejelasan skenario pembelajaran (langkah-langkah kegiatan pembelajaran : pendahuluan, inti, dan penutup). Terlihat jelas bahwa mahasiswa masih memerlukan pemahaman tentang indikator pencapaian kompetensi, berbagai metode pembelajaran yang tepat. Secara keseluruhan penulisan RPP masuk dalam kategori baik.

Hasil yang diperoleh berdasarkan instrumen berupa Lembar Kerja Analisis Pembelajaran yang merupakan keterampilan mengajar dengan menerapkan pendekatan Scientific secara benar terlihat pada tabel 2 di bawah ini.

Tabel 2. Aspek Kompetensi Keterampilan Mengajar

\begin{tabular}{|c|c|c|c|c|c|c|}
\hline \multirow[t]{2}{*}{$\begin{array}{l}\mathrm{N} \\
\mathrm{O}\end{array}$} & \multirow[t]{2}{*}{$\begin{array}{l}\text { Aspek } \\
\text { yang } \\
\text { diamati }\end{array}$} & \multicolumn{4}{|c|}{$\begin{array}{c}\text { Skor Peer Teaching } \\
\mathrm{Ke}-\end{array}$} & \multirow[t]{2}{*}{ Kriteria } \\
\hline & & I & II & III & $\begin{array}{l}\text { ra } \\
\text { ta } \\
- \\
\text { ra } \\
\text { ta }\end{array}$ & \\
\hline 1 & $\begin{array}{l}\text { Melakuka } \\
\text { n } \\
\text { apersepsi } \\
\text { dan } \\
\text { motivasi }\end{array}$ & 2,11 & $\begin{array}{l}2,1 \\
5\end{array}$ & $\begin{array}{l}2,2 \\
1\end{array}$ & $\begin{array}{l}2, \\
1 \\
6\end{array}$ & $\begin{array}{l}\text { Tidak } \\
\text { baik }\end{array}$ \\
\hline 2 & $\begin{array}{l}\text { Penguasa } \\
\text { an materi } \\
\text { dalam } \\
\text { tema } \\
\text { yang } \\
\text { disajikan }\end{array}$ & 2,25 & $\begin{array}{l}2,2 \\
7\end{array}$ & $\begin{array}{l}2,3 \\
0\end{array}$ & $\begin{array}{l}2, \\
2 \\
7\end{array}$ & $\begin{array}{l}\text { Tidak } \\
\text { baik }\end{array}$ \\
\hline 3 & $\begin{array}{l}\text { Menerapk } \\
\text { an }\end{array}$ & 2,75 & $\begin{array}{l}3,2 \\
1\end{array}$ & $\begin{array}{l}3,6 \\
3\end{array}$ & $\begin{array}{l}3, \\
1\end{array}$ & $\begin{array}{l}\text { Kurang } \\
\text { baik }\end{array}$ \\
\hline
\end{tabular}




\begin{tabular}{|c|c|c|c|c|c|c|}
\hline & $\begin{array}{l}\text { strategi } \\
\text { pembelaja } \\
\text { ran yang } \\
\text { mendidik }\end{array}$ & & & & 9 & \\
\hline 4 & \begin{tabular}{|l|} 
Penerapa \\
n \\
pendekata \\
n \\
scientific
\end{tabular} & 2,87 & $\begin{array}{l}3,0 \\
3\end{array}$ & $\begin{array}{l}3,4 \\
9\end{array}$ & $\begin{array}{l}3, \\
1 \\
3\end{array}$ & $\begin{array}{l}\text { Kurang } \\
\text { baik }\end{array}$ \\
\hline 5 & $\begin{array}{l}\text { melaksan } \\
\text { akan } \\
\text { penilaian } \\
\text { autentik }\end{array}$ & 2,30 & $\begin{array}{l}2,7 \\
3\end{array}$ & 3,0 & $\begin{array}{l}2, \\
6 \\
8\end{array}$ & $\begin{array}{l}\text { Kurang } \\
\text { baik }\end{array}$ \\
\hline 6 & $\begin{array}{l}\text { memanfa } \\
\text { atan } \\
\text { sumber } \\
\text { belajar/m } \\
\text { edia } \\
\text { dalam } \\
\text { pembelaja } \\
\text { ran }\end{array}$ & 3,63 & $\begin{array}{l}3,7 \\
1\end{array}$ & $\begin{array}{l}3,7 \\
3\end{array}$ & $\begin{array}{l}3, \\
6 \\
9\end{array}$ & baik \\
\hline 7 & $\begin{array}{l}\text { memicu } \\
\text { dan/atau } \\
\text { memeliha } \\
\text { ra } \\
\text { keterlibat } \\
\text { an } \\
\text { peserta } \\
\text { didik } \\
\text { dalam } \\
\text { pembelaja } \\
\text { ran }\end{array}$ & 3,89 & $\begin{array}{l}3,9 \\
0\end{array}$ & $\begin{array}{l}3,9 \\
5\end{array}$ & $\begin{array}{l}3, \\
9 \\
1\end{array}$ & baik \\
\hline 8 & $\begin{array}{l}\text { menggun } \\
\text { akan } \\
\text { bahasa } \\
\text { yang } \\
\text { benar dan } \\
\text { tepat } \\
\text { dalam } \\
\text { pembelaja } \\
\text { ran } \\
\end{array}$ & 2,65 & $\begin{array}{l}2,9 \\
7\end{array}$ & $\begin{array}{l}3,2 \\
6\end{array}$ & $\begin{array}{l}2, \\
9 \\
6\end{array}$ & $\begin{array}{l}\text { Kurang } \\
\text { baik }\end{array}$ \\
\hline 9 & \begin{tabular}{|l|} 
Penutup \\
Pembelaja \\
ran
\end{tabular} & 3,95 & $\begin{array}{l}4,2 \\
7\end{array}$ & $\begin{array}{l}4,5 \\
9\end{array}$ & $\begin{array}{l}4, \\
2 \\
7\end{array}$ & baik \\
\hline & Rata-rata & 2,93 & $\begin{array}{l}3,1 \\
4\end{array}$ & $\begin{array}{l}3,3 \\
5\end{array}$ & $\begin{array}{l}3 \\
1 \\
1 \\
4\end{array}$ & $\begin{array}{l}\text { Kuran } \\
\text { g baik }\end{array}$ \\
\hline
\end{tabular}

1 = sangat tidak baik, $2=$ tidak baik, $3=$ kurang baik, $4=$ baik, $5=$ sangat baik. Penetapan kriteria dengan pembulatan.

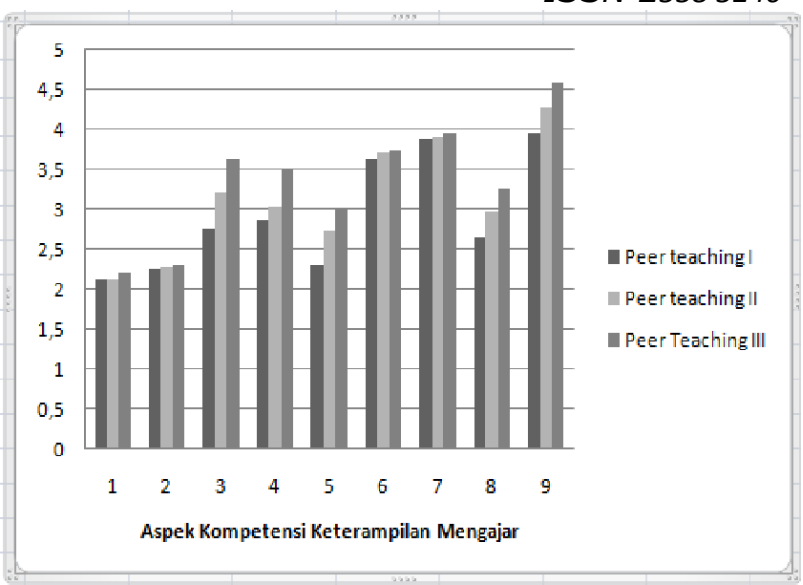

Gambar 1. Skor rata-rata Peer Teaching

Dari tabel 2 di atas terlihat bahwa hanya 3 aspek kompetensi yang termasuk kategori baik yaitu memanfaatan sumber belajar/media dalam Pembelajaran; memicu dan/atau memelihara keterlibatan peserta didik dalam pembelajaran; dan Penutup Pembelajaran. Enam aspek lainnya berada pada kategori tidak baik dan kurang baik. Rata-rata skor terendah berada pada aspek Melakukan apersepsi dan motivasi dan Penguasaan materi dalam tema yang disajikan, dengan skor masing-masing 2,16 dan 2,27. Dua aspek kompetensi yang menyangkut strategi pembelajaran berada pada kategori kurang baik, yaitu aspek Menerapkan strategi pembelajaran yang mendidik (rata-rata skor 3,19) dan Penerapan pendekatan scientific (rata-rata skor 3,13). Hal ini disebabkan rendahnya penguasaan materi dan menggunakan bahasa yang benar dan tepat dalam pembelajaran (kategori kurang baik). Mahasiswa calon guru terfokus dalam penyajian materi sehingga tidak memperhatikan metode dan pendekatan pembelajarannya. Ini didukung dengan penilaian autentik dengan kategori kurang baik (rata-rata skor 2,68.

Dari gambar 1 di atas terlihat bahwa tidak ada perbedaan yang signifikan rata-rata skor kompetensi pada peer teaching I, II, dan III. Diperoleh bahwa aspek kompetensi Melakukan apersepsi dan motivasi memiliki rata-rata skor terendah, dan aspek penutup pembelajaran memeliki rata-rata skor tertinggi. Ada perbedaan yang signifikan antara pendahuluan dan penutup pembelajaran. Secara menyeluruh diperoleh bahwa kompetensi keterampilan mengajar mahasiswa calon guru fisika berada pada kategori kurang baik.

Kompetensi keterampilan mengajar guru tidak terlepas dari PPP. Dari tabel 1 
diperoleh bahwa aspek PPP tentang Kejelasan skenario pembelajaran (langkah-langkah kegiatan pembelajaran: pendahuluan, inti, dan penutup) berada pada kategori kurang baik. Jelas, mahasiswa calon guru fisika belum menguasai pembuatan skenario pembelajaran sesuai dengan KD, KI, dan tujuan pembelajaran sesuai dengan materi pembelajaran. Walaupun PPP berada pada kategori baik (rata-rata skor 3,72) tetapi kompetensi keterampilan mengajar berada pada kategori kurang baik. Ini menunjukkan bahwa mahasiswa calon guru fisika memerlukan latihan yang lebih intensif sehingga mereka bisa terampil dalam pembelajaran di kelas. Penguasaan materi mahasiswa harus ditingkatkan melalui pembelajaran setiap mata kuliah. Dosen dalam pembelajaran di kelas harus menjadi model bagi mahasiswa calon guru, baik dari kompetensi kognitifnya maupun dalam kompetensi keterampilan mengajarnya.

\section{IV.KESIMPULAN}

Berdasarkan hasil penelitian dan analisis data hasil penelitian disimpulkan bahwa:

1. kompetensi keterampilan mengajar mahasiswa calon guru fisika berada pada kategori kurang baik dengan rata-rata skor 3,14 . Rendahnya kompetensi keterampilan mengajar ini disebabkan: (1) aspek penguasaan materi yang berada pada kategori tidak baik (rata-rata skor 2,27); (2) aspek PPP tentang Kejelasan skenario pembelajaran (langkah-langkah kegiatan pembelajaran : pendahuluan, inti, dan penutup) berada pada kategori kurang baik (rata-rata skor 3,27).

2. Skor terendah aspek kompetensi keterampilan mengajar mahasiswa calon guru fisika adalah Melakukan apersepsi dan motivasi (rata-rata skor 2,16) diikuti oleh aspek penguasaan materi (rata-rata skor 2,27). Sedangkan Skor tertinggi aspek kompetensinya adalah penutup pembelajaran (rata-rata skor 4,27).

3. Skor terendah aspek PPP adalah Kesesuaian perumusan tujuan pembelajaran dengan indikator pencapaian kompetensi dan Kesesuaian metode dengan tujuan, materi, dan karakteristik peserta didik, dengan skor 3,26. Sedangkan skor tertingginya adalah Ketepatan kegiatan penutup dalam pembelajaran (rata-rata skor 4,18).
4. Mahasiswa calon guru fisika memerlukan peer teaching yang lebih intensif sebelum mereka praktek langsung di sekolah sehingga mereka bisa terampil dalam pembelajaran di kelas.

5. Penguasaan materi fisika mahasiswa calon guru harus menjadi perhatian dosen melalui pembelajaran setiap mata kuliah.

6. Dosen dalam pembelajaran di kelas harus menjadi model bagi mahasiswa calon guru, baik dari kompetensi kognitifnya maupun dalam kompetensi keterampilan mengajarnya.

\section{DAFTAR PUSTAKA}

[1] Dedi Supriadi. 1999. Mengangkat Citra dan Martabat Guru. Yogyakarta: Adicita Karya Nusa.

[2] I Wayan Darmadi dan Nurasyah Dewi Napitupulu, 2013, Pengembangan Kompetensi Guru dan Motivasi berprestasi Siswa melalui Model pembelajaran Konstruktivis dalam meningkatkan Hasil belajar Fisika Siswa di SMP Sekotamdya Palu. Palu: Lembaga Penelitian Untad.

[3] Kemdikbud, 2013, Permendikbud No.54 Tahun 2013 tentang Standar Kompetensi Lulusan, Jakarta: Kemdikbud

[4] Kemdikbud, 2013, Permendikbud No.64 Tahun 2013 tentang Standar Isi, Jakarta: Kemdikbud

[5] Kemdikbud, 2013, Permendikbud No.65 Tahun 2013 tentang Standar Proses, Jakarta: Kemdikbud.

[6] Kemdikbud, 2013, Permendikbud No.66 Tahun 2013 tentang Standar Penilaian, Jakarta: Kemdikbud.

[7] Kemdikbud, 2013, Permendikbud No.67 Tahun 2013 tentang Kerangka Dasar dan Struktur Kurikulum SD/MI, Jakarta: Kemdikbud

[8] Kemdikbud, 2013, Permendikbud No.81A Tahun 2013 tentang Implemenasi Kurikulum 2013, Jakarta: Kemdikbud

[9] Musdalifah Nurdin dan Dewi Tureni. 2013. Prosiding Seminar Nasional Sains dan Matematika II. Palu: Untad Press. 
[10] Salam, Burhanuddin. 1997. Pengantar Pedagogik. Bandung: Rineka Cipta.

[11] Suminarsih, Model Praktik Pembelajaran Terbimbing Tuntas pada Pendidikan dan pelatihan Kurikulum 2013 bagi Guru Sasaran di LPLM Jawa Tengah. http://www.lpmpjateng.go.id/web/i ndex.php/arsip/artikel/841-modelpembelajaran 